\title{
PRÉ-MOLAR RETIDO: RELATO DE CASO
}

Diego Augusto Ferreira JORGE, Douglas PEREIRA, Cleverson Luciano TRENTO, Eduardo MORESCHI, Vilmar Divanir GOTTARDO

Paciente P. T., gênero feminino, 17 anos, compareceu ao Centro Universitário de Maringá - CESUMAR por indicação ortodôntica para extração de dente retido em região de corpo de mandíbula do lado direito, próximo ao ápice dos pré-molares. Foi realizado exame clínico e solicitado exame radiográfico intrabucal, sendo detectada a presença de um segundo pré-molar retido e segundo molar decíduo irrompido com ausência de rizólise. Sendo assim, por indicação ortodôntica optou-se pela remoção do pré-molar retido, devido a impossibilidade de tracionamento ortodôntico. Através desta salientamos a importância da apuração detalhada durante o exame clínico e radiográfico onde a decisão de se manter ou não o dente em questão, foi decisiva para o tratamento e prognóstico.

Palavras-chave: Dente Impactado; Dente Decíduo; Ortodontia. 